DOI 10.15826/Lurian.2020.1.1.4

УДК 929:616.89(438)

\title{
Greetings From the Polish Society of Neuropsychology
}

\section{Aleksander Romanowich Luria (1902-1977) and the Heritage of His Neuropsychological Thought in Poland}

\author{
Maria Pąchalska \\ President of the Polish Society of Neuropsychology, \\ Chair of Neuropsychology and Neurorehabilitation, \\ Cracow University, \\ Cracow, Poland
}

\section{Приветствие от Польского общества нейропсихологии}

\section{Александр Романович Лурия (1902-1977) \\ и наследие его нейропсихологической мысли в Польше}

\author{
Мария Панхальская \\ Президент Польского общества нейропсихологии, \\ кафедра нейропсихологии и нейрореабилитации, \\ Краковский университет, \\ Краков, Польша
}

Corresponding author.E-mail:neuropsychologia23@02.pl

It is a great privilege and joy for me that I can write greetings to the Lurian Journal edited by Professor Janna Glozman and dedicated to the popularization of the scientific thought of the eminent Russian scientist Alexander Romanowicz Luria (Александр Романович Лурия). During more than 50 years of scientific work of A.R. Luria made a great contribution to the development of various fields of psychology, such as psycholinguistics, psychophysiology, developmental psychology, ethnopsychology, etc. He also contributed to the emergence of a new discipline of science - neuropsychology, as well as contributing to the development of cultural psychology and inspiring the emergence of the neuropsychology of creativity. Luria was one of the few Soviet scientists whose work was read and appreciated in the West. Many of his colleagues also have significant 
scientific achievements. These include Bein (1964), Tsvetkova (1985), Akhutina (1975), Glozman (1999, 2012), Kaczmarek (1984, 2012), Kądzielawa (1986), Klimkowski (1975, 1976), Maruszewski (1966, 1974), and Tłokiński (1986) in Poland; Laaksonen (1986), Christensen (1975) in Denmark; Bisiach in Italy; Luzzatti (1978) in Finland; Brown (1988), Tonkonogy and Goodglass (1981), and Goldberg (2001) in the USA.

When discussing the beginnings of neuropsychology in Poland it is worth pointing out that Aleksandr R. Luria was the first scientist who defined neuropsychology as a science dealing with relationships between brain structures and mental activities. This approach to the subject of neuropsychology is associated with the traditions of the Russian psychophysiological school, which comprised many eminent researchers, enough to mention Pavlov, Anokhin and Bernstein. Luria creatively developed the concept of the "functional system" introduced by Anokhin. The most important feature of this system is not only its complex multilevel structure, but also its dynamic, plastic character. This means that it may undergo changes of both its components and general structure. Luria emphasized that such an organization of the brain was closely linked to higher cortical activities.

It is also worth recalling that Luria laid the foundations for the theory of a symptom. He emphasized that the symptom does not point directly to the place of brain damage, because it results from a disruption of the entire system. Therefore, in order to specify the real nature of the symptoms observed it is imperative to underpin the "basic defect" that leads to the appearance of the disorders. It is possible to delineate a syndrome specific to the "defect" that underline the syndrome. This type of assessment is known as syndromological analysis. It was commonly used in medical diagnosis and Luria modified it by including neuropsychological analysis of particular syndrome. In this way he has utilized his medical background. After all he did receive a doctorate in medicine.

Luria was born on July 16, 1902 in Kazan. His father, Roman Albertowich Luria, was a well-known and respected doctor, while his mother was a stomatologist. For the reader of the Lurian Journal, it may be interesting to note that the mother graduated from extramural studies in Poland, because at that time in Tsarist Russia, women were not admitted to universities. After passing the school-leaving certificate exam, A. R. Luria joined the Faculty of Social Sciences at the University of Kazan in 1918. He was to pass his examinations early and graduated in 1921.

His work on reaction time and related thought processes was well recognized and in 1923 he received a position at the Institute of Psychology in Moscow. From the beginning, Luria showed very wide interests, and was among others a founder of the students' Social Sciences Society. Not everyone knows that he organized a psychoanalytical circle when he worked as an assistant at the Institute of Labour Organization in Kazan. As a result of these interests he produced a book which was published in the United States under the title The Nature of Human Conflicts (Luria, 1932). The author describes in it attempts to study emotional states by registering motor and vascular reactions. In his mind, thanks to cooperation with Vygotsky, understanding is born from the relationship between the brain and mental activities. 
In 1925, Luria visited Berlin, where he met, among others, Levin, Köhler and Goldstein, and in 1929 during the International Congress of Psychologists he met many American psychologists and the eminent linguist Roman Jakobson. This is how his interest in aphasia was born. However, particularly important for Luria's scientific activity was cooperation with Lev Vygotsky, whom he met in 1924. Psychological expeditions under Vygotsky to Central Asia in 1931-1932 aimed at an evaluation of the empirical verification of Vygotsky's assumptions as to the socio-cultural basis of human cognitive processes, including the impact of school education on thinking, perception, and memory. These studies met with harsh criticism on the part of the authorities at the time, as did Vygotsky's whole theory. In consequence, his supporters were forced to move from Moscow to Kharkov. Among the Kharkov group were such well known researchers as Leontiev, Zaporozhets, Elkonin, and Galperin.

After coming back to Moscow, Luria took a job at the Institute of Neurosurgery. Here he began to conduct research, which over time brought him worldwide fame and laid the foundation for a new field of scientific and clinical research - neuropsychology. During this time, he began medical studies and obtained a medical diploma in 1937.

His work in a hospital in the Urals in 1941 made possible extensive research in the field of neuropsychology on a wide base of clinical material. This was caused by the influx of wounded from the frontline in the battle against Nazi Germany. He had the opportunity to work with soldiers with gunshot wounds to the brain. This created the foundation for the development of knowledge about the functioning of the brain based on the disorders observed. Particularly important was the research on speech disorders, which resulted in the publication of the book Post-traumatic Aphasia. At that time Luria cooperated with many outstanding psychologists, such as Zeigarnik, Zaporozhets and Rubinstein, as well as neurologists - Perelman and Basin.

In 1944, Luria returned to work at the Institute of Neurosurgery in Moscow. Starting from 1945 he also worked at Moscow State University and was instrumental in establishing the Faculty of Psychology at this university, where he later headed the Institute of Pathology and Neuropsychology. However, he was removed from in 1950 on the basis of the fact that his theory was not compatible with Pavlov's teaching. Luria then took a job at the Institute of Defectology, which resulted in work on the importance of language for child development. This applies especially to the regulating function of speech as developed later in Poland in the therapy of behavioural disorders in people with brain damage. In 1956 Luria returned to neuropsychology. He made contacts with many prominent psychologists from abroad, including J. Piaget, J. Bruner, W. Janus, W. Cannon, K. Pribram, and J.W. Brown. He also received many invitations and in 1960 he visited the United States. Later, many of his students and friends visited him in Moscow.

Both in his early neuropsychological work at the end of the 1830s as well as throughout his post-war academic career, Luria focused on research into aphasia, focusing on the relationship between language, thinking and cortical functions, especially on the development of compensatory mechanisms in aphasia. 
Two main case studies were to have an impact on the work of Polish neuropsychologists; these being published a few years before his death. This is the case of the Russian journalist S. V. Shereshevski, with seemingly unlimited memory, partly due to the occurrence of the phenomenon of synesthesia. This case was presented in the book On Memory, which had no limits. Another known book by Luria and also translated into Polish is the Man with a shattered world, which presents the poignant case study of Zasetsky, a young man who suffered a brain injury as a result of a gunshot wound. These examples illustrate Luria's main working methods, combining classic and remedial approaches. They were widely discussed and served as inspiration when developing two textbooks on neuropsychology published in Poland.

A special friendship connected Luria with Jason W. Brown, who remains in close contact with Polish neuropsychologists. This friendship began during Brown's long stay in Moscow in 1976. These scholars then carried out lively correspondence, sharing their insights on brain function and on methods of treating patients after brain injuries. Many of these methods were implemented in patient therapy at the Center for Cognition and Communication founded at the time by Professor Brown in New York. The clients of this center, at which the first author of this note has been a consultant for several years, were and still are mainly patients after brain injuries. Luria's cooperation with Brown has, among others, contributed to the emergence of microgenetic theory, introduced into clinical practice in Poland and successfully under development until now.

Luria and Polish neuropsychologists have also been in close contact and friendship. First this involved his immediate students: Mariusz Maruszewski, Marcel Klimkowski and Bożydar L. J. Kaczmarek. They created neuropsychological schools at the University of Warsaw and the Lublin based Maria Curie-Sklodowska University as well as neurolinguistics. These activities are still being developed by students of these scholars.

Luria's activities in Poland have been highlighted in a special way. He receives the title of Doctor Honoris Causa of the Maria Curie-Sklodowska Lublin University in 1974 from the hands of the rector of The Maria Curie-Skłodowska University, Prof. Wiesław Skrzydło (see Figure 1).

A special Polish accent recognizing this scholar is the jubilee issue of the international periodical Aphasiology, whose editor was Prof. Bożydar L. J. Kaczmarek. The value of this publication is that, in contrast to other works of this type, it presents the works of Luria students both from the field of Western neuropsychology as well as from the former Socialist Bloc.

Among Luria's Polish friends was also Maria Susułowska of the Jagiellonian University's Institute of Psychology. During Luria’s visit to Krakow and in warm correspondence, both scientists emphasized the importance of the in-depth study of individual cases as opposed to the ever-growing interest in group research. The discussion particularly included the phenomenon that the same brain damage has a different impact on the lives of different people. For example, a disorder of musical hearing is a great problem for a professional musician, while speech disorders are the tragedy of a lawyer or a teacher. It is worth adding that Susułowska was a lover of music and this observation could be influenced by 


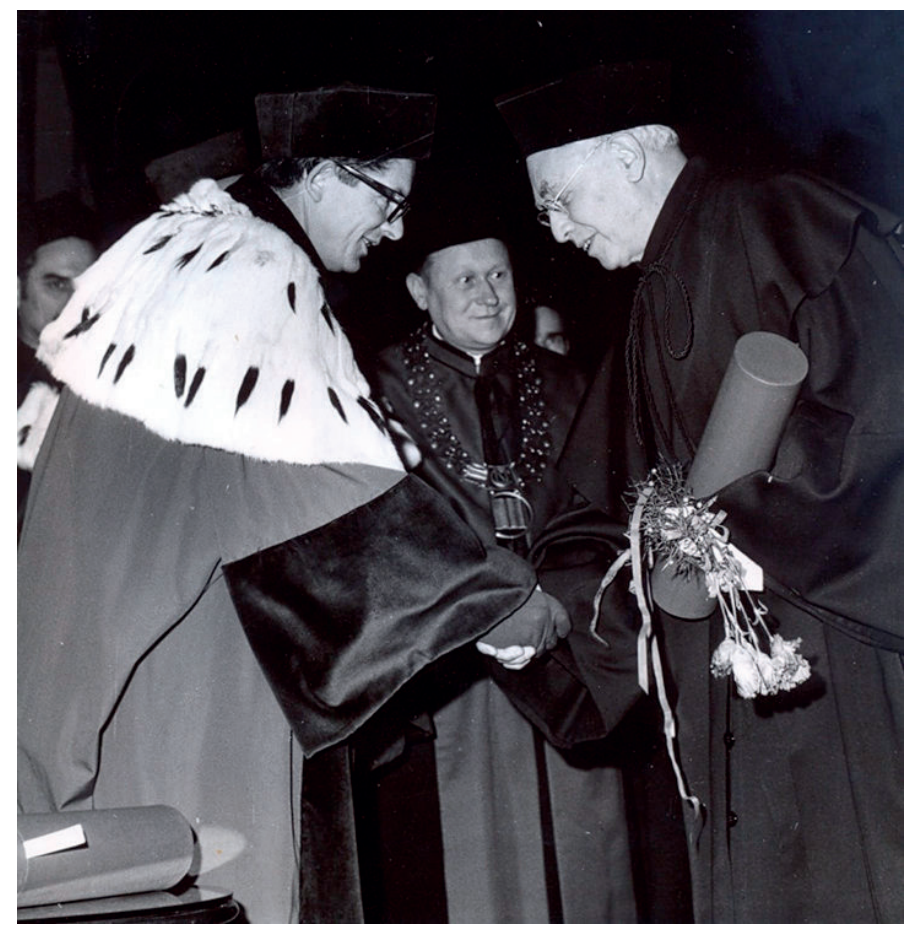

Figure 1. Alexander R. Luria (right) receives the title of Doctor Honoris Causa in 1974 from the hands of the rector of The Maria Curie-Skłodowska University, Prof. Wiesław Skrzydło. From Pąchalska, Kaczmarek, \& Kropotov, 2014

their joint visits to concerts at the Krakow Philharmonic Concert Hall. It is also highly probable that these conversations allowed Luria to realize how great the impact of brain damage on a patient's entire life is: on its cognitive, emotional and professional aspects.

Lurian approach to the problem of the localization of the higher mental functions is widely developed in Poland. According to the said:

...higher mental functions as complex functional systems cannot be located in narrow zones of the cerebral cortex or in isolated groups of cells, on the basis of complex systems of jointly operating zones, each of which contribute to the implementation of complex mental processes and which can be located in completely different, sometimes distant parts of the brain (Fundamentals of Neuropsychology, 2014, chap. 2, p. 3).

This finds its confirmation in the discovery of previously unknown forms of speech disorders beside those described by Luria as a result of new neurotechnologies. Of particular significance are neuromarkers enabling the precise diagnosis of brain disorders with the use of quantitative electroencephalography (qEEG) and Event Related Potentials (ERPs).

In recognition of this immense contribution to the development of Polish neuropsychology, the long-term President of the Polish Neuropsychological Society - Prof. Maria 
Pąchalska - honoured Luria, posthumously, with its highest award - The Copernicus Prize 2002 (see Figure 2). This took place during the International Congress of Neuropsychology in Moscow on the occasion of the $100^{\text {th }}$ anniversary of Luria's birth.

In Poland, we teach our students the Lurian approach. They also know that the Russian School organized several congresses devoted to Alexander R. Luria. The Congress on the 110th anniversary of Luria's birth in 2012 turned out to be a great scientific success. First of all, it showed that the Russian school of neuropsychology is still important and that Luria's ideas are still valid. It is not surprising then that many well-known neuroscientists from both Russia and around the world actively participated in the congress. In the satellite conference a lively discussion was conducted, involving, among others, such famous researchers as Michael Cole, Elkhonon Goldberg, and Antonio Puente. Moreover, a Memorial Plaque was unveiled there, while one of the lecture halls at the Institute of Psychology at the Lomonosov University in Moscow was named The Alexander R. Luria Auditorium. At the same time presented was an interesting exhibition of Luria's achievements.

Above of all, the congress contributed to the founding, by Professor Janna Glozman, of the Society of Applied Neuroscience (SAN) with significant support from the President of the Polish Society of Neuropsychology Professor Maria Pąchalska, and at the same time
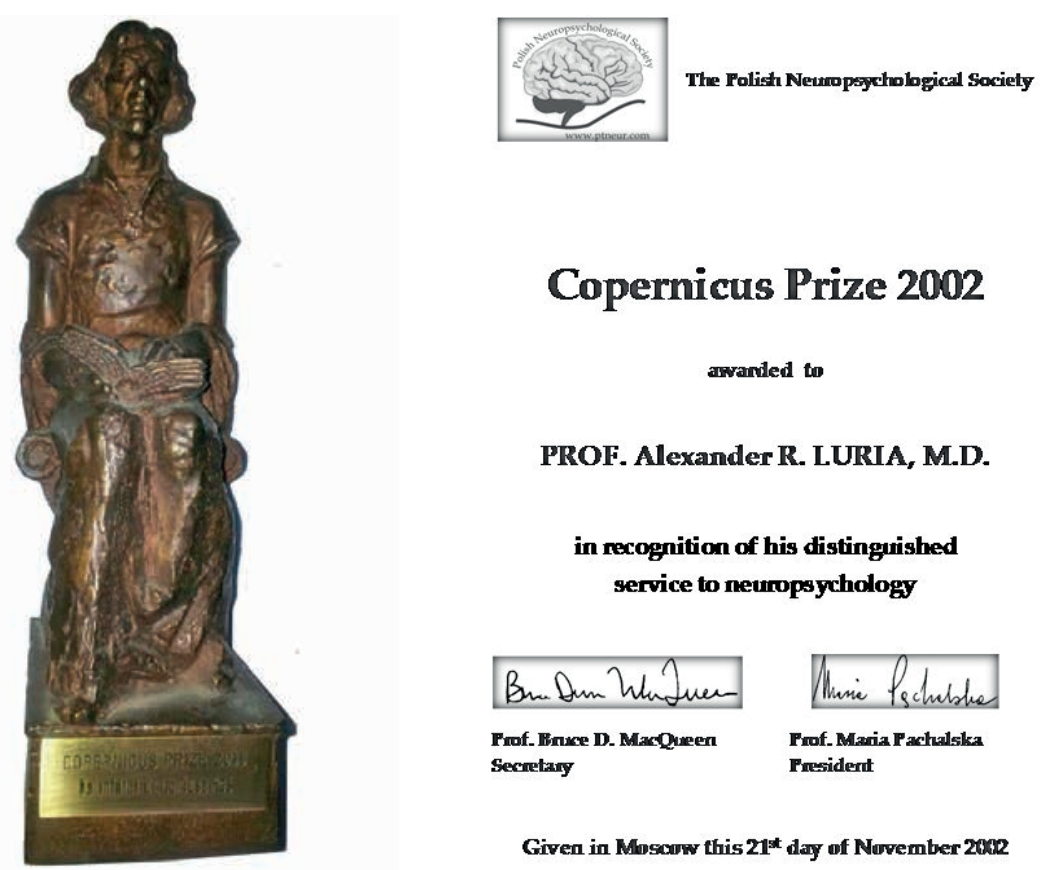

Copernicus Prize 2002

anwanded to

PROF. Alexander R. LURIA, M.D.

in recognition of his distinguished service to neuropsychology
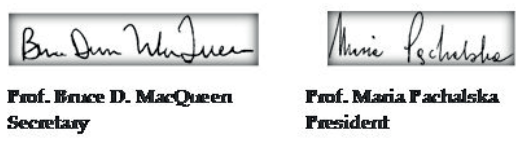

Prof.Maria Pachalska

Fresident

Given in Moscuw this 21*t day of Nuvember 2002

Figure 2. The highest award of the Polish Neuropsychological Association - The Copernicus Prize 2002 - posthumously presented to mark the $100^{\text {th }}$ anniversary of the birth of A. R. Luria. S o u r c e: the library of M. Pąchalska 
a representatives of the International Society of Neuropsychology. The members of the society are not only renowned Russian scientists as well as young researchers, both from Moscow and other areas of Russia, starting from St. Petersburg and ending in Kamchatka, but also scholars from all over the world. The functions of society vice-president are held by Prof. Maria Pąchalska and Prof. Bożydar Kaczmarek.

The Journal Acta Neuropsychologica, published in Poland by MEDSPORTPRESS and edited by Maria Pąchalska, has popularized both the achievements of Alexander Romanovich Luria and the Russian school of neuropsychology by publishing many scientific articles, and when needed, other reports on significant scientific events devoted to the popularization of the Lurian approach. The heritage of Luria's neuropsychological thought is great. Speaking as Horace, he built a work more durable than bronze [Exegi monumentum aere perennius]. His scientific thought has inspired and continues to inspire many scholars in the world. These are not only his students and colleagues, but also their scientific descendants.

I would like to express my deepest congratulations and good wishes to Professor Janna Glozman for continuing this immortal work in the Lurian Journal.
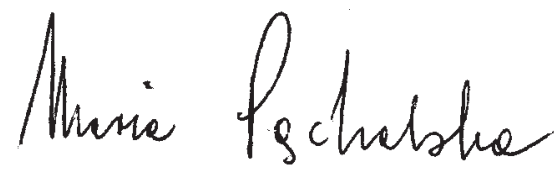

Original manuscript received January 31, 2020

Revised manuscript accepted February 15, 2020

To cite this article: Pąchalska, M. (2020). Aleksander Romanowich Luria (1902-1977) and the heritage of his neuropsychological thought in Poland. Lurian Journal, 1 (1), 20-26. DOI: 10.15826/Lurian.2020.1.1.4 